Arab Univ. J. Agric. Sci., Ain Shams Univ., Cairo, 13(2), 297 - 307, 2005

\title{
PHYSIOLOGICAL EXPLORATION OF CERTAIN MAIZE INBRED LINES AND HYBRIDS BY USING RAPID METHODS TECHNIQUE 1. GENOTYPIC DIFFERENCES
}

[18]

\author{
El-Koomy ${ }^{1}$, M.B.A.; A.A. Abdel-Gawad ${ }^{2}$; A.M.A. Abo-Shetaia ${ }^{2}$ \\ and G.M.A. Mahgoub ${ }^{1}$
}

\begin{abstract}
Identification of specific physiological differences among maize genotypes (six inbred lines, four single crosses and four three-way crosses) to drought would be useful to plant breeders for improving selection criteria. Two field experiments were conducted in optimum and stress moisture conditions at Gemmeiza Agricultural Research Station in 2001 and 2003 growing seasons. The treatments were 14 genotypes, (six inbreds and eight hybrids), which were separately established under three irrigation treatments in split plot design with four replications. The genotypes were compared under water-deficit conditions on the basis of certain rapid techniques to determine leaf area index (LAI), photosynthetic efficiency (photo), canopy temperature depression (CTD), stomatal conductance (SC) and chlorophyll (CHL) content which were deleteriously affected by water stress in the sensitive genotypes. Results revealed that values of LAI, photosynthetic efficiency, canopy temperature depression, stomatal conductance and chlorophyll content of maize hybrids surpassed those of inbred lines. This was true at 30, 45 and 60 days after planting (DAP). Differences among maize hybrids and among inbred lines were significant at different growth stages for the same studied traits, except of the LAI for the inbreds, at 30 DAP and CTD for the hybrids at 30 as well as 60 DAP. Detecting certain physiological criteria, i.e. LAI, photosynthetic efficiency (photo), canopy temperature depression (CTD), stomatal conductance (SC) and chlorophyll content (Chl) could be used as reliable techniques to explore the physiological activity of maize genotypes at early stages of growth and may be recommended in screening different genotypes in maize breeding programs.
\end{abstract}

Key words: Maize, Inbred lines, Hybrids, Leaf area index (LAI), Photosynthetic (Photo) efficiency, Canopy temperature depression (CTD), Stomatal conductance (SC), Chlorophyll (Chl) content

1- Maize Res. Section, Field Crops Inst., ARC, Giza, Egypt

2- Agron. Dept., Fac. Agric., Ain Shams Univ, Shobra El-Khema, Cairo, Egypt

(Received December 5, 2004)

(Accepted December 20, 2004) 


\section{INTRODUCTION}

Drought tolerance in plants as a complex trait and the mechanism for its expression and/or inheritance are not well understood. Several attempts have been made to physiological studies in maize to develop effective screening methods for drought tolerance.

In maize breeding programs, the need to identify superior genotypes as early as possible is of great importance. Developing some physiological criteria would help in this respect. Hanson and Nelson (1980) reported that the ideal screening techniques should be rapid, accurate, nondestructive to plant tissues or organs, applicable to large number of germplasm in an early growth stage and has a high creditability in relation to actual performance of crop under field conditions. Several physiological criteria for selecting tolerant genotypes have been proposed. Steduto and Hasiao (1998) used leaf area index to screen maize genotypes tolerant to drought. Leaf area index is possible to be estimated directly from spectral data. Shah and Paulsen (2003) found that moisture stress diminished leaf area rapidly. Photosynthetic efficiency is another criteria used by several researchers to assess drought tolerance (Gwizdek, 1989; Human et al 1990; Jesko and Navara, 1990; Grzesiak, 1991; Hu-Ch et al 1993). Canopy temperature may be useful in predicting water stress in maize (Khera et al 1992). Allen et al (2003) showed that there was a good relationship between canopy to air temperature difference and water status. This relationship could be used as useful criteria in crop irrigation management. Also, leaf temperature increased linearly with a slope of about 0.75 with increasing air temperature. Ray and Sinclair (1997) compared eight maize hybrids in response to soil drying. Among the eight hybrids examined, there were statistical differences in the fraction of transpirable soil water. They found genotypic differences for stomatal responses to soil moisture stress. In this respect, Fischer et al (1998) concluded that stomatal conductance and canopy temperature depression should be further investigated as potential indirect selection criteria for yield, measurement costs for stomatal conductance and canopy temperature depression (and leaf greenness) are certainly in the same realm as the cost of measuring yield itself. Whereas, Tang and Turner (1999) reported that decreasing soil water content decreased the stomatal conductance and photosynthetic rate and consequently, reduced plant growth. Havaux and Lannoye (1983) showed that the chlorophyll fluorescence induction phenomenon provides a simple non-destructive method for investigating effects of drought on plants. However, Sergey et al (1998) concluded that chlorophyll fluorescence measurements could be used to screen genotypes for abiotic tolerance. Whereas, Shah and Paulsen (2003) found that drought stress and high temperature decreased photosynthesis and productivity of wheat by different mechanisms. Stomata closed as soil moisture content decreased.

The objective of this investigation was to examine the credibility of the abovementioned five techniques as screening criteria for genotypic maize drought stress in breeding programs.

\section{MATERIAL AND METHODS}

Two field trials were carried out at Gemmeiza Agricultural Research Station, Middle Delta, Egypt in 2001 and were

Arab Univ. J. Agric. Sci., 13(2), 2005 
repeated in 2003 growing seasons. The first field trial included six inbred lines under three irrigation treatments. The second one included eight hybrids under the same irrigation treatments. The inbred lines used in this study were, Gm-2, Gm4, Gm-18, Gm-21, Sd-7 and Sd-63, whereas, the studied eight single and three-way hybrids that were derived from these inbred lines are presented in Table (1).

Table 1. Names and origin of single crosses (SC) and three-way crosses (TWC) used in this study

\begin{tabular}{|ll|}
\hline \multicolumn{1}{|c|}{ Hybrids } & Origin \\
\hline 1. SC-21 & Gm-2 $\times$ Sd-63 \\
2. SC-22 & Gm-21 x Sd-63 \\
3. SC-23 & Gm-4 x Sd-63 \\
4. SC-24 & Gm-18 x Sd-63 \\
5. TWC-321 & SC-21 x Sd-7 \\
6. TWC-322 & SC-22 $\times$ Sd-7 \\
7. TWC-323 & SC-23 x Sd-7 \\
8. TWC-324 & SC-24 x Sd-7 \\
\hline
\end{tabular}

The genetic materials were kindly provided by Maize Research Sec., Field Crops Res. Inst., Agric. Res. Center, Egypt.

Three irrigation regimes i.e. irrigation of 100,85 and $70 \%$ of evapotranspiration (ET), which represent the application of 3282, 2880 and 2522.6 $\mathrm{m}^{3} /$ fad (one faddan $=4200 \mathrm{~m}^{2}$ ) in the first growing season and 3352.8, 2939.9 and $2527.1 \mathrm{~m}^{3} /$ fad in the second growing season, respectively as shown in Table (2).
Time of irrigation was done at 21,36 , $51,66,81$ and 96 DAP for the six irrigations with the corresponding water requirement (WR) treatment (Table, 2). Water requirements were calculated according to Keller and Karmeli (1975) as follows:

ET crop $=\mathrm{KC}$ x ETO Where:

ET crop $=$ water requirement, i.e. actual evapotranspiration in $\mathrm{mm}$ day $^{-1}$

ETO = potential evapotranspiration in mm day $^{-1}$

$\mathrm{KC}=$ constant of maize crop

Daily evapotranspiration was obtained from the Central Lab of Agricultural Climate (CLAC), Ministry of Agriculture and Soil Reclamation. Potential ET and quantity of irrigation water were calculated according to the daily WR, their data are presented in Table (2) in 2001 and 2003 growing seasons. Moreover, Table (3) shows some meteorological variables recorded at El-Gemmeiza Agric. Res. Sta.

The combination between the three water requirement (WR) treatments and the genetic materials were arranged in split-plot design with four replications, where WR treatments were allocated in the main plots and maize genetic materials were assigned to the sub-plots. To avoid the vigorous growth of maize crosses, inbred lines were grown in a separately trial. Experimental units was consisted of 6 ridges, $70 \mathrm{~cm}$ in width and $3 \mathrm{~m}$ in length. The previous winter crop was wheat in the two growing seasons. Date of planting was June $23^{\text {rd }}$ and June $4^{\text {th }}$ in 2001 and 2003 seasons, respectively. The inbred lines were planted using 2-3 kernels/hill, whereas hybrids were planted using 1-2 kernels /hill, then 
Table 2. Irrigation requirements $\left(\mathrm{m}^{3} / \mathrm{fad}\right)$ for maize during 2001 and 2003 growing seasons

\begin{tabular}{|c|c|c|c|c|c|}
\hline \multirow{2}{*}{$\begin{array}{c}\text { Date of } \\
\text { irrigation }\end{array}$} & \multirow{2}{*}{$\mathrm{KC}^{1}$} & \multirow{2}{*}{$\mathrm{ETO}^{2}$} & \multicolumn{3}{|c|}{ Irrigation water quantity $\left(\mathrm{m}^{3} / \mathrm{fad}\right)$} \\
\hline & & & $100 \% \mathrm{ET}$ & $85 \% \mathrm{ET}$ & $70 \% \mathrm{ET}$ \\
\hline \multicolumn{6}{|c|}{2001 growing season } \\
\hline $11 / 7$ & 0.56 & 6.89 & 338.1 & 287.4 & 236.7 \\
\hline $26 / 7$ & 0.76 & 7.13 & 341.1 & 290.2 & 238.9 \\
\hline $11 / 8$ & 0.97 & 7.70 & 440.5 & 374.4 & 308.4 \\
\hline $26 / 8$ & 1.14 & 7.74 & 555.9 & 472.5 & 389.1 \\
\hline $9 / 9$ & 1.22 & 7.50 & 538.0 & 457.3 & 376.6 \\
\hline $22 / 9$ & 1.19 & 7.21 & 468.5 & 398.2 & 372.9 \\
\hline Total $^{3}$ & & & 2682.4 & 2280.0 & 1922.6 \\
\hline \multicolumn{6}{|c|}{2003 growing season } \\
\hline $11 / 7$ & 0.56 & 7.12 & 348.1 & 295.9 & 243.7 \\
\hline $26 / 7$ & 0.76 & 7.45 & 362.5 & 308.1 & 253.8 \\
\hline $11 / 8$ & 0.97 & 7.66 & 477.3 & 405.7 & 334.1 \\
\hline $26 / 8$ & 1.14 & 7.57 & 517.5 & 439.9 & 362.3 \\
\hline $9 / 9$ & 1.22 & 7.20 & 559.5 & 475.6 & 391.7 \\
\hline $22 / 9$ & 1.19 & 6.50 & 487.9 & 414.7 & 341.5 \\
\hline Total $^{3}$ & & & 2752.8 & 2339.9 & 1927.1 \\
\hline
\end{tabular}

1. KC : Constant of maize crop

2. ETO : Potential evapotranspiration in $\mathrm{mm} \mathrm{day}^{-1}$

3. The grand total of irrigation water does not include planting irrigation, which was $600 \mathrm{~m}^{3} / \mathrm{fad}$.

Table 3. Meteorological data at Gemmeiza zone during 2001 and 2003 growing seasons

\begin{tabular}{|ccccc|}
\hline Month & $\begin{array}{c}\text { Max tem } \\
{ }^{\circ} \mathrm{C}\end{array}$ & $\begin{array}{c}\text { Min tem } \\
{ }^{\circ} \mathrm{C}\end{array}$ & $\begin{array}{c}\text { Max RH } \\
\%\end{array}$ & $\begin{array}{c}\text { Min RH } \\
\%\end{array}$ \\
\hline & \multicolumn{2}{c|}{ 2001 growing season } \\
\hline June & 32.7 & 20.7 & 87 & 34 \\
July & 34.1 & 23.2 & 88 & 46 \\
August & 34.7 & 24.0 & 88 & 43 \\
September & 32.4 & 21.6 & 87 & 41 \\
October & 30.0 & 19.2 & 87 & 38 \\
\hline & \multicolumn{5}{c}{2003 growing season } \\
\hline June & 35.1 & 23.4 & 87.2 & 32.9 \\
July & 35.1 & 24.8 & 87.8 & 45.4 \\
August & 35.7 & 24.6 & 88.0 & 44.5 \\
September & 33.2 & 22.2 & 88.8 & 41.2 \\
October & 29.9 & 19.7 & 89.9 & 39.5 \\
\hline
\end{tabular}


thinned to one plant/hill before the first irrigation. Nitrogen fertilizer as urea $(46 \% \mathrm{~N})$ form was added at the rate of $120 \mathrm{~kg} \mathrm{~N} /$ fad in two equal doses, before the first and the second irrigation, while phosphorus fertilizer was added in the form of calcium super phosphate $(15.5 \%$ $\left.\mathrm{P}_{2} \mathrm{O}_{5}\right)$ at the rate of $31 \mathrm{~kg} \mathrm{P}_{2} \mathrm{O}_{5} / \mathrm{fad}$. Other cultural practices were applied as recommended.

\section{Physiological parameters}

Five physiological parameters, i.e. leaf area index, photosynthetic efficiency $\left(\mu \mathrm{mol} \mathrm{m} \mathrm{m}^{-2} \mathrm{~S}^{-1}\right.$, canopy temperature depression $\left({ }^{\circ} \mathrm{C}\right)$, stomatal conductance (mol $\left.\mathrm{m}^{-2} \mathrm{~S}^{-1}\right)$ and chlorophyll content $\left(\mathrm{mg} / \mathrm{m}^{-2}\right)$ were determined at 30, 45 and 60 DAP. LAI was measured using the whole plant by LAI-2000 plant canopy analyzer. Measurements of LAI are closely related to the canopy interaction of solar radiation. The other four traits were measured using the upper third leaf blade of the plant. Canopy temperature depression represents the difference between the outer air and inside leaf temperatures $\left({ }^{\circ} \mathrm{C}\right)$ and were obtained at the midday hour $(14: 00-16: 00 \mathrm{am})$ of the day before irrigation. Photosynthetic efficiency (Photo), air \& leaf temperature and SC were measured by Licor-6200 porometer (LI6200, Li-Cor, Lincoln, NE, USA). Chlorophyll content was determined as SPAD unit (Soil and Plant Analysis Department) of Minolta Co. These units were transformed to $\mathrm{mg} / \mathrm{m}^{2}$ as described by Monje and Bugbee, (1992) as follows:

$$
[\mathrm{Chl}]=80.05+10.4 \text { SPAD.502] }
$$

\section{Statistical analysis}

The obtained data concerning the response of inbred lines or hybrids to WR treatments were statistically analyzed according to Steel and Torrie (1980). The genotypic differences among inbred lines and those among hybrids are exhibited in this study.

\section{RESULTS AND DISCUSSION}

\section{Leaf area index}

Mean values of leaf area index (LAI) increased gradually as plant growth advanced toward flowering. It was 0.37 , 0.66 and 1.83 for inbred lines and 0.66 , 1.14 and 2.53 for hybrids at 30,45 , and 60 DAP, respectively. This increase was due mainly to the increase in number of effective leaves and it's area by the advancement in plant growth. Data in Table 4 indicate clearly that the studied inbred lines and hybrids within all growth stages, i.e. 30, 45 and 60 DAP differed significantly respecting LAI, except that of inbred lines after 30 DAP, for which was not significant. The two inbred lines Gm18 and Sd-7 exhibited the highest LAI values at all growth stages. Among single crosses, SC 23 and SC 22 had the highest values of LAI at 60 DAP (2.34 and 2.20, respectively). However, TWC 323 exhibited the highest LAI value (3.41) at the same growth stage. Increasing LAI values as plant growth advanced toward flowering was due mainly to the differences in photosynthetic activity of the leaves, i.e. internal factor and/or the differences in light penetration and distribution on leaf surface of the crop canopy as a result of differences in leaf arrangement among different genotypes. Similar results were obtained by Moursi, (1979); Schmidt and Colvill (1979); Dale et al (1980), Wilhelm and Nelson, (1984); Jacobs et al (1989); Muchow et al (1990); Tang 
and Turner, (1999) and Lizaso et al (2003), who reported that the expansion of leaves differed among maize genotypes.

\section{Photosynthetic efficiency ( $\mu \mathrm{mol} \mathrm{m} \mathbf{~ S}^{-2}$ )}

The photosynthetic efficiency of plant leaves was estimated for inbred lines and hybrids as the rate of $\mathrm{CO}_{2}$ consumption during different growth periods, i.e. 30, 45 and 60 DAP. Data in Table (4) show that mean values of photosynthetic efficiency slightly increased by plant growth until flowering being 15.88, 16.56 and $17.27 \mu \mathrm{mol} \mathrm{m}^{-2} \mathrm{~s}^{-1}$ for inbreds and 16.71, 17.40 and $18.43 \mu \mathrm{mol} \mathrm{m} \mathrm{m}^{-2} \mathrm{~s}^{-1}$ for hybrids, at 30, 45 and 60 DAP, respectively.

Both inbred lines and hybrids significantly differed respecting photosynthetic efficiency at all growth stages until flowering. The highest mean values of this trait were obtained for the inbred line Sd7 and TWC 323 at the three growth stages. It increased from 17.53 to $18.08 \mu$ mol $\mathrm{m}^{-2} \mathrm{~s}^{-1}$ for Sd-7 and from 19.93 to $21.53 \mu$ mol m $\mathrm{m}^{-2} \mathrm{~s}^{-1}$ for TWC 323 at 30 and 60 DAP, respectively. This increase in photosynthetic efficiency by plant growth may be due to the increase in solar radiation and the biotic activity of different maize genotypes. The above-mentioned results suggested that photosynthetic efficiency could be controlled by the nature of the stocks and the prevailing environmental conditions. Gwizdek, (1989) reported that mean values of photosynthetic rate increased gradually as plant growth were advanced toward flowering and (or) grain filling period. They added also that hybrids exhibited the higher photosynthetic rate than the inbred lines.

Stomatal conductance $\left(\mathrm{mol} \mathrm{m} \mathrm{m}^{-2} \mathrm{~s}^{-1}\right)$
Stomatal conductance as the main criteria for drought tolerance of maize plants is sensitive to number of environmental conditions such as light, humidity and $\mathrm{CO}_{2}$ concentration. Efforts to predict SC have focused mainly on empirical analysis of stomatal response to variations in single factor. Mean values of SC slightly differed as plant grows. It increased from 0.12 to $0.14 \mathrm{~mol} \mathrm{~m}^{-2} \mathrm{~s}^{-1}$ for inbred lines and from 0.14 to 0.15 for hybrids, at 30 and 60 DA P, respectively. The obtained results showed also that inbred lines were significantly of smaller values compared with hybrids at all growth stages. It is worth to note that no big difference in SC values between inbred lines and hybrids. The inbred lines Sd-7, Gm-4 and Gm-18 and the three-way crosses TWC 323 and 324 possessed the highest values of stomatal conductance especially at 60 DAP indicating that these genotypes could be considered as drought tolerant ones. The above-mentioned results are in a good agreement with those obtained by Saccard et al (1996) and Tang and Turner (1999).

\section{Chlorophyll content $\left(\mathrm{mg} \mathrm{m}^{-2}\right)$}

Total chlorophyll content was estimated directly in the field using the intact leaves by a portable chlorophyll meter. Chlorophyll content in maize inbred lines and hybrids canopy suffered considerable changes at different growth stages. Mean values of chlorophyll content increased markedly by plant growth (Table, 4). For inbred lines, their mean values were $349.3,357.4$ and $390.0 \mathrm{mg} \mathrm{m}^{-2}$ at 30,45 and 60 DAP, whereas they were 422.0, 445.0 and $465.1 \mathrm{mg} \mathrm{m}^{-2}$ for maize hybrids 
at the same growth stages. It should be noted that inbred lines and hybrids significantly differed at 30, 45 and 60 DAP. At 60 DAP, the inbred lines $\mathrm{Gm}-2$, followed by Sd-63 and Gm-18 had the highest values of chlorophyll content $(431.9,422.0$ and $410.6 \mathrm{mg} \mathrm{m}^{-2}$, respectively). On the other hand, TWC 323, TWC 321 and SC 22 exhibited the highest values of chlorophyll content at all growth stages. These results indicated that these genotypes contain more chlorophyll than the other studied genotypes.

\section{Canopy temperature depression $\left({ }^{\circ} \mathrm{C}\right)$}

The high values of CTD indicate the difference in leaf water content was due to water stress (Table 4). Drought tolerant genotypes should have low CTD values. Mean values of CTD slightly differed at different growth stages. It mainly dependent on weather temperature and water status within plant tissues. In drought conditions, genotypes that possessed lower values of CTD are considered as drought tolerant. Line Sd-7 and TWC 323 are considered to be the most tolerant one, since they had the lowest CTD values especially around flowering (0.825 and $0.883{ }^{\circ} \mathrm{C}$ for $\mathrm{Sd}-7$ and TWC 323 at 60 DAP, respectively). Brich et al (1998) showed that the ability of a plant canopy to continue extracting and transpiring water from drying soil and consequently collar to canopy temperature, reduces in turn evapotranspiration and improved plant tolerance to drought.

\section{REFERENCES}

Allen, L.H.; Jr Deyun Pan; K. J. Boote; N.B. Pickering and J.W. Jones (2003). Carbon dioxide and temperature effects on evapotranspiration and water use effi- ciency of soybean. Agron. J., 95: 10711081.

Brich, C.J.; G.L. Hammer and K.G. Rickert (1998). Temperature and photoperiod sensitivity of development in five cultivars of maize (Zea mays L.) from emergence to tassel initiation. Field Crops Res., 55:93-107.

Dale, R.F.; D.T. Coelho and K.P. Gallo (1980). Production of daily green leaves area index for corn. Agron. J., 72: 9991005.

Fischer, R.A.; D. Rees; K.D. Sayre; Z.M. Lu; A.G. Condon and A.L. Saavedra (1998). Wheat yield progress associated with higher stomatal conductance and photosynthetic rate and cooler canopies. Crop Sci., 38: 1467-1475.

Grzesiak, K.S. (1991). Ecological and physiological factors of drought resistance in different genotypes of maize (Zea mays L.). Zeszyty Naukowe Akademii Rolnicezej H. Kollataja, W. Krakowie (C.F. Maize Abst., 9: 2903).

Gwizdek, S. (1989). Rate of photosynthesis in some maize lines and their hybrids. Hodowla Roslin, Aklimatyzacja Nasiennictwo, 33(5-6): 61-72.

Hanson, A.D. and C.E. Nelson (1980). Water: adaptation of crops to droughtprone environments. pp. 77-152. In: Carlson, P.S. (ed.). Biology of Crop Productivity, Academic Press, New York. Havaux, M. and R. Lannoye (1983). Chlorophyll fluorescence induction: a sensitive indicator of water stress in maize plants. Irrigation Science, 4(2): 147-151.

Hu-Ch, S.T.D.; S.S. Yue; Q.Y. Wang; R.Q. Gao and Z.L. Pan (1993). Studies on the relationship between canopy apparent photosynthetic rate and grain yield in high yielding summer maize. Acta Agronomica Sinica, 19(1): 63-69. 
Human, J.J.; W.H. Du-Preez and L.P. De-Bruyn (1990). The influence of plant water stress on net photosynthesis and leaf area of two maize (Zea mays L) cultivars. Agron. And Crop Sci., 164 (3): 194-201.

Jacobs, A.F.; J. Halbersma and C. Przybyla (1989). Behavior of the crop resistance of maize during growing season. IAHS Publication No. 177, 165-173. Jesko, T. and J. Navara (1990). Water uptake, photosynthesis and growth of young maize plants with an excess of $\mathrm{K}^{+}$ and $\mathrm{NO}_{3}{ }^{-}$ions in the root environment. Biologia (Bratislava), 45 (9): 699-708.

Keller, J.K. and D. Karmeli (1975). Trikle Irrigation Design. Rain Bird Sprinkler. Mfg. Crop., pp. 58-61, Glendor, USA.

Khera, K.L.; B.S. Sandhu; C.B. Singh and K. Kumara (1992). Water stress, radiation and plant temperature relationships in maize grown in subtropical region of Northern India. Tropical Ecology, 33(1): 63-71.

Lizaso, J.I.; W.D. Batchelor and M.E. Westgate (2003). A leaf area model to simulate cultivar-specific expansion and senescence of maize leaves. Field Crops Res., 80: 1-17.

Monje, O.A. and B. Bugbee (1992). Inherent limitations of non-destructive chlorophyll meters. A comparison of two types of meters. Hort. Sci., 27: 6971.

Moursi, M.A. (1979). Cereal Crops. pp. 182-237. Anglo-Egyptian Bookshop, Cairo, Egypt.

Muchow, R.C.; T.R. Sinclair and J.M. Bennett (1990). Temperature and solar radiation effects on potential maize yield across locations. Agron. J., 82(2): 338343.
Ray, J.D. and T.R. Sinclair (1997). Stomatal closure of maize hybrids in response to drying soil. Crop Sci., 37(3): 803-807.

Saccard, K.; G. Cornic; J. Brulfert and A. Reyss (1996). Effect of drought stress on net $\mathrm{CO}_{2}$ uptake by Zea leaves. Planta, 199: 589-595.

Schmidt, W.H. and W.L. Colvill (1979). Yield and yield components of Zea mays $\mathbf{L}$ as influenced by artificially induced shade. Crop Sci., 7: 137-140.

Sergey, N.S.; I. Sh. Svetlana; I.M. Alexey; O. Babourina and I.N. Newman (1998). Salinity effect on bioelectric activity, growth, $\mathrm{Na}^{+}$accumulation and chlorophyll fluorescence of maize leaves: a comparative survey and prospects for screening. Aust. J. Plant Physiol., 25: 609-616.

Shah, N.H. and G.M. Paulsen (2003). Interaction of drought and high temperature on photosynthesis and grain filling of wheat. Plant and Soil, 257:219. 226.

Steduto, P. and T.C. Hasiao (1998). Maize canopies under two soil water regimes. II. Seasonal trends of evapotranspiration, carbon dioxide assimilation and canopy conductance as related to leaf area index. Agric. and Forest Meteorology, 89 (3-4): 185-200.

Steel, R.G.D. and J.H. Torrie (1980). Principles and Procedures of Statistics. $2^{\text {nd }}$ Ed. McGraw-Hill Book Company, N.Y.

Tang, C. and N.C. Turner (1999). The influence of alkalinity and water stress on the stomatal conductance, photosynthetic rate and growth of Lupinus angustifolius $\mathrm{L}$ and Lupinus pilosus Murr. Australian J. Exp. Agric., 39: 457464. 
Wilhelm, W.W. and C.J. Nelson (1984). Carbon dioxide exchange rate of tall fes- cue-leaf area $v s$ leaf light basis. Crop Sci., 25:775-778.

بحلة الحاد الجامعات العربية للدراسات والبحوث الزراعية ، جامعة عين شمس ، القاهرة ، 13(2) ، 297 - 307 ، 2005

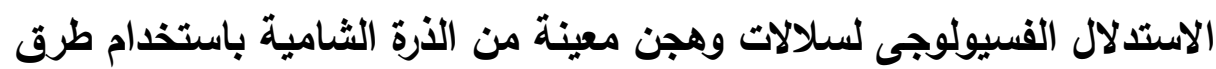
القياس السريعة

\section{1. إختلافات التراكيب الوراثية}

[18]

\section{محمود بيومى عبد الجواد الكومى 1 - عبد العظيم أحمد عبد الجواد²-

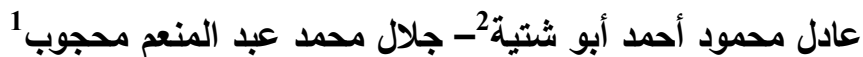

1- قسم بحوث الذرة الثامية - معهة بحوث المحاصيل الحقلية - مركز البحوث الزراعية - الجيزة - مصر معرد

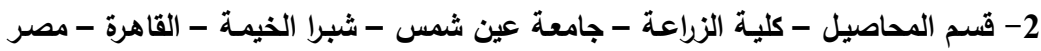

السلالات أو الهجن موضع الدراسة فى القطع

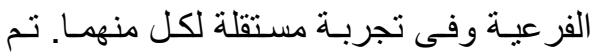

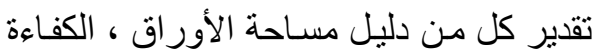

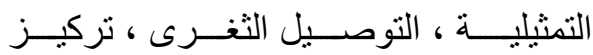

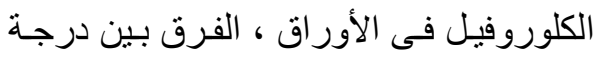
حرارة الورقة والجو المحيط ، بعد الأور 30 ، 30

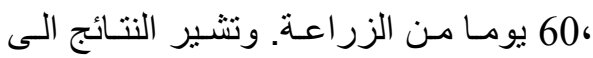

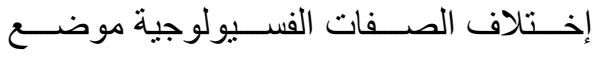

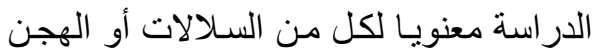

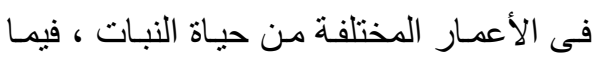

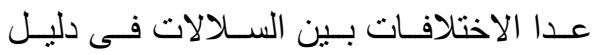

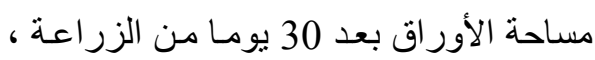

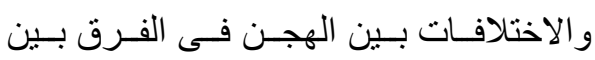

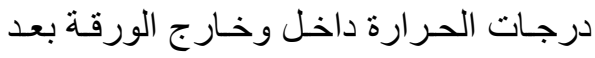

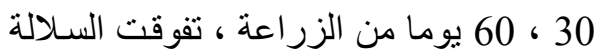

أقيمت تجربتـان حقليتان بمحطة البحوث

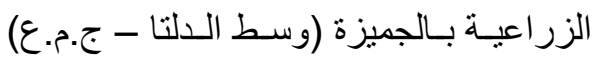

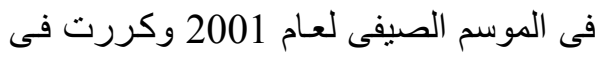
الموسم الصيفى لعـام 2003 لدر اســة إمكانيـة

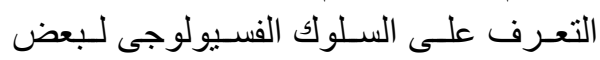

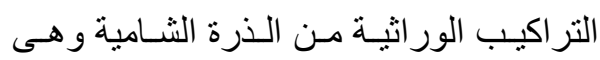

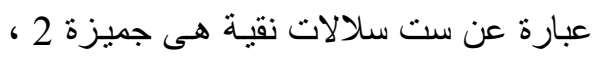

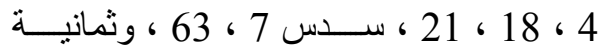

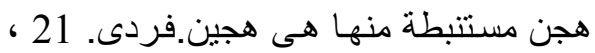
22 ، 23 ، 24 ، 24 ، هجين.ثلاثى. 321 ، 321 ، 322

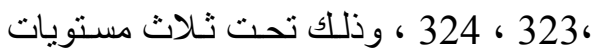

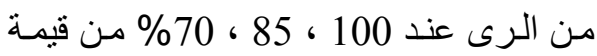

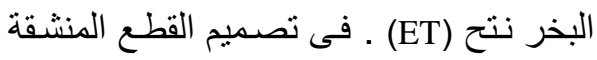

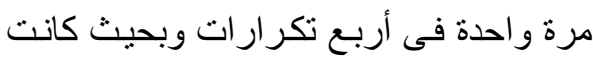
معاملات الرى فى القطع الرئيسية وكل من أن 
الزر اعة. مما يشير الى امكانية استحـدام هذه

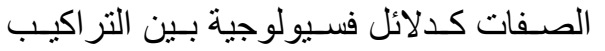

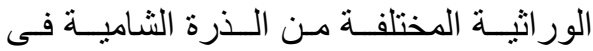
اعمار متباينة من حياة النبات.
ســـس 7 وكـلـل مــن الهجـين الفـردى 23 و الهجين الثلاثى 323 فى مقدار دليل مسـاحة

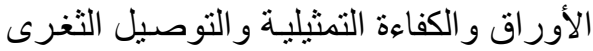
، بينما نقص الفرق بين درجة حرارة الورقة والجو المحيط لهذه التر اكيب الور اثية الثلاثية

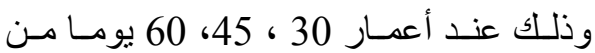

